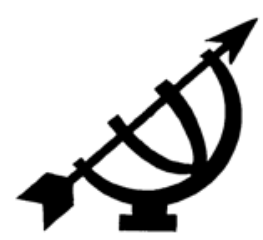

\title{
Appraising the e-readiness of online learning facilitators: key human factors
}

\author{
L. Vermeulen \\ Public Management and Governance \\ School for Social and Development Studies \\ Potchefstroom Campus \\ North-West University \\ POTCHEFSTROOM \\ E-mail: Luni.Vermeulen@nwu.ac.za
}

\section{Abstract \\ Appraising the e-readiness of online learning facilitators: key human factors}

Higher education institutions in South Africa have undergone a number of changes over the past few years. These changes brought about inter alia changed work environments and job demands. One of the new job demands is the need to incorporate technology in teaching and learning, viz. e-learning. Not all job incumbents, however, adapted successfully to these changes, particularly with regard to e-readiness. Such a lack in e-readiness is likely to influence the effectiveness with which an academic employee will fulfil his/her online learning duties. Therefore, it is important to find solutions to overcome the lack of e-readiness.

This article will focus on the role of human resource appraisal, in order to assess the e-readiness of online learning facilitators with a view to improving their online skills and capacity. A number of human factors that can play a role in employee performance and motivation, namely learning styles, personal profile patterns, and pace and style of technology adoption will be briefly outlined, in order to determine the role that these factors could play in assessing the e-readiness of online learning facilitators. 


\section{Opsomming}

\section{Evaluering van die e-gereedheid van web-gerugsteunde leerfasiliteerders: kern menslike faktore}

Hoëronderwysinstellings in Suid-Afrika het die afgelope paar jaar verskeie veranderings ondergaan. Hierdie veranderings het onder andere veranderde werksomgewings en veranderde werksvereistes teweeg gebring. Een van hierdie veranderde werksvereistes is die gebruik van tegnologie in leer en onderrig, naamlik e-leer. Alle posbekleërs het egter nie noodwendig saam met die pos verander nie. Waar daar 'n tekort aan e-gereedheid ervaar word, sal die effektiwiteit waarmee die akademiese personeellid sy/haar aanlyntake vervul, beïnvloed word en daarom is dit belangrik om oplossings vir die gebrek aan e-gereedheid te vind.

Hierdie artikel fokus op die rol van prestasie-evaluering met die doel om die e-gereedheid van 'n aanlyn-leerfasiliteerder te evalueer ten einde sy/haar vaardighede en kapasiteit te verbeter. 'n Aantal menslike faktore wat 'n rol kan speel in 'n werknemer se prestasie-evaluering en -motivering, naamlik leerstyle, persoonlike werksprofiele en die pas en styl wámrmee werknemer aanpas by die gebruik van tegnologie, sal kortliks uiteengesit word met die doel om die rol wat hierdie faktore in die evaluering van e-gereedheid van 'n web-gerugsteunde leerfasiliteerder speel, te bepaal.

\section{Introduction}

Higher education institutions (HEIs) in South Africa have undergone a number of changes in recent years. These changes resulted in inter alia altered work environments and job demands. One of the changed job demands is the need to incorporate technology in teaching and learning, viz. e-learning. The job incumbent, in this case the online learning facilitator, therefore needs to change with the changed job demands. All job incumbents did, however, not necessarily change in accordance with the new demands associated with their jobs and therefore did not embrace the use of technology in teaching and learning.

The changed job demands placed on employees may not be congruent with a particular employee's skills, task preferences, or career ambitions (Rees \& Porter, 2003:282). It is known that change in the workplace is usually associated with resistance to some extent (Robbins, 2003:559-560; Hunsaker, 2001:380). It is essential that employees remain motivated to obtain institutional goals and objectives and continue to provide quality services to learners, 
irrespective of changes in job demands. However, when employees experience a lack of e-readiness, the effectiveness with which an academic employee will fulfil his/her online learning duties are likely to be influenced. It is therefore important to determine solutions to overcome the lack of e-readiness.

Prior to the implementation of corrective action, employees need to be assessed during a performance appraisal process, in order to determine whether a lack of e-readiness occurs, as well as the extent to which there is a lack of e-readiness. The performance appraisal process should thus make provision for the assessment of ereadiness. Presently, neither the literature of human resource performance appraisal nor the literature of e-readiness makes provision for an assessment instrument pertaining to e-readiness. This article therefore aims to contextualise a theoretical instrument in which an e-readiness assessment instrument can be included in the performance appraisal process to assess the e-readiness of online learning facilitators at HEls.

A number of key human factors that can play a role in employee performance and motivation, viz. learning styles, personal profile patterns and pace and style of technology adoption are explained in order to determine the role that these factors play in the e-readiness of an online learning facilitator. These factors can be considered in the performance appraisal process as well as in the drafting of a development plan. Furthermore, the human resource appraisal process can play a role in motivating staff with the aim of enhancing performance. Therefore, the role and value of selected motivating factors in human resource appraisal are briefly explained.

\section{Background: e-readiness and e-readiness assessment}

Previous research on e-readiness indicates that various e-readiness assessments have been conducted in the past few years, and specific tools for such assessments of e-readiness have been developed. The purpose of e-readiness assessment is to provide a benchmark and guide the development process (Bridges.org, 2005a:1). These assessment tools were primarily used to assess the e-readiness of countries (particularly developing countries), governments, companies (for example, in the banking and property sectors), and to a limited extent HEIs (EIU, 2007:1-3; Bridges.org, 2005a:1-10; Mutula, 2006; Machado, 2007:73-74; McConnell International, 2001:1-23; Maugis et al., 2005:313-342; Choucri et al., 2003; Ifinedo, 2005; SchoolNet Africa, 2003; Bridges.org, 2005b:1-4; Masternewmedia, 2002). All these tools focus primarily on facilities, 
connectivity, accessibility, hardware, software, the digital divide, technological status, policies and regulations. The person using the technology is only mentioned as role player, but his/her e-readiness as such is not assessed with these tools.

Machado (2007:72-82) refers to an e-readiness assessment tool that has been developed specifically for HEls as a result of a focus group study. The particular assessment tool focuses on e-readiness factors such as the ability of HEls (in terms of accessibility, connectivity, technological status, policies) and the capacity of institutional stakeholders. The tool tested the "feelings" of participants towards implementation of e-learning of which the outcomes were positive. Furthermore, the assessment identified the various abilities required at administrative level, instructor level, and student level. However, the tool did not assess the readiness of the e-user as such. It is thus apparent that current performance appraisal systems do not provide for the assessment of the e-readiness of online learning facilitators since such an assessment instrument is not yet available.

The e-readiness of online learning facilitators (and assessment thereof) is important for various reasons. For the purpose of this article, the following illustrates the importance of e-learning, and by implication emphasises the e-readiness of online learning facilitators:

- From an ethical viewpoint, the online learning facilitator is responsible for service delivery to the customer, in this case the learner. The principle of serviceability (widely regarded as an ethical concept) should be endorsed by most HEIs.

- For goal accomplishment and institutional performance, it is necessary for all employees to fulfil their duties and have or develop the necessary skills to do so.

- As e-learning is often used as means for distance learning, persons residing in remote areas will also have access to education, which is enshrined in the South African Constitution as a basic human right (RSA, 1996).

- Education through e-learning will contribute towards addressing the training and development needs of the community, which is also a human rights responsibility.

It is therefore evident that improving the e-readiness of online learning facilitators is imperative not only for the individual empower- 
ment of online learning facilitators, but also for the organisational effectiveness of HEls.

\section{Research methodology and philosophical vantage point}

The following question can be asked: how can online learning facilitators at HEls be assessed to determine their level of e-readiness? The purpose of this article is to contribute towards scholarly knowledge in the field of human resource management, by determining how to assess online learning facilitators at HEls, in order to determine their level of e-readiness. Therefore, attention is given to the following objectives:

- to determine the need for and role of human resource appraisal in addressing the level of e-readiness of online learning facilitators at HEIs; and

- to determine the human factors influencing e-readiness of online learning facilitators in a changing higher education environment, with a specific focus on learning styles, personal profile patterns, and the use of the technology adoption cycle.

Considering the above-mentioned factors, a matrix upon which online learning facilitators can be plotted during the performance appraisal process can be developed. Training and development interventions that will best assist online learning facilitators to increase their level of e-readiness can subsequently be determined.

The study has a normative approach and an experiment will be conducted at a later stage against which the thinking portrayed in this article will be tested. The experiment does not form part of the research reported on in this article. 1 The qualitative data derived from the results of a focus group discussion are the only data used (Vermeulen, 2006). The article therefore has a theoretical approach and aims at providing an innovative application of existing theory on human resource performance appraisal, in order to assess an online learning facilitator's e-readiness.

A constructivist approach to teaching and learning requires academic employees to alter their regular thinking approach. Should

1 This is a pilot study and an e-readiness matrix will be constructed as part of a further, broader study. 
traditional teaching and learning aim to realise a constructivist worldview, different ways of thinking and doing will be required (Gubukcu, 2008:155; cf. Gulati, 2008:183). The majority of HEls realised the need to include technology in teaching and learning to provide for the need of learners in a global village. In this respect, the use of elearning has become increasingly important. Not only has it opened up new teaching and learning opportunities, but it has also provided access to resources beyond the borders of those traditionally available Therefore, in the context of global technological development, emphasis on the use of technology, and the increased use and need for teaching and learning by digital means, academic staff at HEls are expected to develop their own computer literacy and ability to keep up with technological development and to incorporate technology in their teaching.

Online learning facilitators and theorists have recognised the constructivist approach as essential for developing learner-centred strategies. Furthermore, emerging online learning literature often refers to learning as a social constructivist experience (Gulati, 2008:184). When learners participate in archetypal e-learning activities such as structured online discussions, collaborative online activities, online assessment, and interactive course material, the constructivism in online pedagogy is supported (Mason as quoted by Gulati, 2008: 184). Similarly, it can be assumed that this is applicable to online learning facilitators.

\section{Human resource performance appraisal: theoretical framework}

According to Schuler (1981:211), performance appraisal is

a formal structured system of measuring and evaluating an employee's job-related behaviours and outcomes to discover how and why the employee is presently performing on the job and how the employee can perform more effectively in future so that the employee, the organisation and society all benefit.

Performance appraisal thus refers to the assessment of employees pertaining to their work performance (evaluative part), as well as their potential for further development (Rademan \& De Vos, 2001: 54; cf. also Grobler et al., 2002:260, 266).

A performance management system stems from an organisation's vision and objectives, which are linked to the human resources planning process (Nykodym, 1996:1; cf. Thomson \& Mabey, 2001:189- 
190; Miner \& Crane, 1995:237; DPSA, 2002:2-3). The performance appraisal targets of individuals are therefore set within the framework of organisational objectives and organisational strategy. A performance appraisal process will take place to determine whether an individual's performance coincides with what is expected in terms of the organisational framework, objectives, and strategies. Training, development, and reward outcomes will subsequently be identified during the performance appraisal process. The effectiveness of the process will be evaluated to determine its contribution in terms of organisational performance in general, which will allow for changes and improvements that may lead to a development plan (cf. Thomson \& Mabey, 2001:189-190; cf. Miner \& Crane, 1995:237). It is important that the direct link and integration of organisational goals and objectives with individual performance targets are re-emphasised to online learning facilitators. Particularly when employees experience a lack of e-readiness (which can very likely be associated with resistance to change in job demands), it is necessary to place these new job demands and their importance in terms of organisational effectiveness at large, into perspective.

The objectives of performance appraisal most relevant to this article are "to identify training and development needs", "to facilitate communications and involvement", "to motivate and control employees". One can add the allocation of "financial or other rewards" as incentive. It is evident that through the performance appraisal system and determining perceived lack of e-readiness managers should determine how to encourage academic staff to be involved, motivated, and committed, as well as provide the necessary training and development where shortcomings are identified.

Performance appraisal can be regarded as one of the most significant communications between managers and subordinates, as it can either enhance or diminish the effects of other human resource management activities (Rademan \& De Vos, 2001:54). It is imperative that managers at HEls ensure that the performance appraisal system will contribute to various factors, such as motivation and the improvement of skills, to ultimately bring academic staff to an ereadiness level that allows them to feel comfortable with and committed to e-learning. It is also important that academic staff understand their role in e-learning and be able to motivate themselves in terms of personal growth and development. It is vital that employees interpret the worth and integrity of their jobs. Performance appraisal can supply the information that assists in this regard, and offers a framework for accountability and feedback. 
As for communication and involvement, research has found that employees are more positively inclined to the performance appraisal process when it provides opportunity for involvement and satisfies their needs (Nykodym, 1996:2). When objectives and plans are discussed candidly, employees respond more favourably to the process. It is imperative for managers and employees to mutually agree on the intended purpose, process and functions pertaining to performance appraisal (Nykodym, 1996:4).

It could be argued that owing to the scale at which organisational change was implemented in South African HEls, performance appraisal systems should be revisited to determine the need for adjustments, for which a needs-analysis may be necessary. The foundation for such an analysis would be the corporate or strategic plan of the HEI that indicates organisational objectives and broad policy guidelines. These objectives typically flow down to faculties, departments, sections and individuals, which will influence performance targets. Such organisational objectives may hold significant training implications and may call for an organisational development approach (Wilson, 2005:141). In the case of changed job demands, such as the need to incorporate technology in teaching and learning, managers at HEls need to consider such an analysis, in order to determine how the performance appraisal system can be adjusted in accordance with organisational and job demand changes to include the e-learning aspect of an employee's job profile.

One of the most significant factors managers should take cognisance of when job demands change and organisations undergo transformation, is the motivation of staff. When employees resist change, such as the incorporation of technology in teaching and learning, their resistance may be associated with a lack of motivation. A number of factors pertaining to motivation play a role in employees' performance. Reference has been made to the importance of motivating staff in the above-mentioned paragraphs. The factors concerning motivation are subsequently outlined in the following sections.

\subsection{Goal setting}

As indicated in the previous section, employees tend to be more motivated and inclined to the performance appraisal process when it provides opportunity for involvement. When goals are openly discussed, employees respond more favourably to the process of performance appraisal. A significant motivating factor that plays a role 
in employees' performance and their attitude towards the performance appraisal process therefore is goal setting.

It is, however, interesting to note that research on goal commitment has found that the same level of commitment and performance is reached when goals are assigned to employees by managers as when employees take part in the setting of their own goals (Curtis, 1994:41). Furthermore, assigned goals strongly influence employees' personal goals. That "new" goals are now assigned to academic staff who are expected to act as online learning facilitators due to changed job demands should therefore not be a restricting factor to motivation. However, in practice, resistance to new ideas at various levels is still evident with several online learning facilitators.

The only exception where assigned goals do not contribute to better performance, but actually lead to poorer performance is when the assigned goals are given with brief, abrupt instructions and with the absence of a rationale (Curtis, 1994:41; Locke \& Latham, 1990:241). When employees are provided with a credible reason for a challenging goal it can assist in increasing goal commitment (Li \& Butler, 2004:38; Locke \& Latham, 1990).

Once an academic employee has been plotted on the technology adoption cycle, it will be easier to understand to what extent a rationale behind the changed job demands needs to be provided. People adapt to change, including technological change, at different rates and some (for example innovators and visionary employees) are unlikely to require a rationale, but would value the opportunity to experiment with something new. It could be accepted that for the majority of employees, however, an explanation needs to be provided.

In a focus group discussion held with online learning facilitators at a $\mathrm{HEI}$, where resistance to the use of technology in teaching and learning is eminent, it was found that employees were unhappy with the additional job demands they were being tasked with without a proper explanation as to the importance of the new task (Vermeulen, 2006). These employees indicated that a new demand, such as elearning, that will add to their workload and require of them to obtain a new skill will need to be introduced gradually and with a rationale indicating the benefit to learners that cannot be accomplished with traditional classroom teaching and learning. The need for training in this respect was also emphasised (Vermeulen, 2006). 
Individuals who set effective goals and combine that with suitable learning strategies, as well as sufficiently assess the requirements of learning tasks, tend to perform at higher levels than those who do not (Garavalia \& Gredler, 2008:221). During the performance appraisal process, online learning facilitators will be assessed on these goals relating to their e-learning responsibilities. It will therefore be in the interests of both the employee and the HEI to set effective goals.

Since the added responsibility of acting as an online learning facilitator can cause the employee to resist change to some extent, it is necessary to consider the goals set carefully as well as the manner (self-set; assigned) in which these goals are set. When an employee portrays a significant lack of e-readiness, it could be sensible to commence with moderate goals and gradually increase the difficulty level of goals in order to provide the employee with the opportunity to mature into the role of online learning facilitator.

\subsection{Incentives and rewards}

Another motivating factor influencing the performance of employees, as well as their perceptions (positive or negative), in the performance management process is incentives and rewards. Callahan et al. (2003:2518-2519) indicate that incentives have both a direct and indirect effect on task performance. Usually a direct relationship between financial incentives and task performance can be found. Incentives are, however, usually linked to goals, either implicitly or explicitly. Piece-rate incentives used in combination with assigned goals lead to higher self-set goals.

According to expectancy theory, employees are motivated to perform when they believe their effort will lead to an appreciated reward. Research indicates that there is a relationship between incentives and higher self-efficacy, as well as higher self-set goals (Callahan et al., 2003:2518-2519). Depending on where an employee is plotted on the technology adoption cycle, it might be necessary to couple the changed job demand - acting as online learning facilitator - to an incentive or reward. The relation between incentives and rewards, learning styles, and pace and style of technology adoption is illustrated in a later section.

\subsection{Intrinsic motivation}

Shamir (1996:151) indicates that intrinsic motivation originates from within an individual and refers to an interaction between an individual and a task. When an individual performs an activity for its 
own sake and enjoys performing it, intrinsic motivation is awakened. Therefore, intrinsic motivation is induced when an individual feels interest, pleasure, and enthusiasm in taking on task-related activities. The individual is self-motivated towards task participation (Bainbridge, s.a.).

For intrinsic motivation to be awakened, it is imperative that a task provide challenges. Intrinsically motivated individuals will seek to master a task and have a need for competence, which is fulfilled when the individual meets the challenge and achieves mastery. Rewards or incentives do not result in competence; rather, competence results when the individual masters activities in which he/she is engaged in. For a person who is intrinsically motivated, the emphasis is on self-administered rewards. Intrinsic motivation relies furthermore on self-determination and a direct relationship between outcomes, such as creativity and innovation, and the presence of intrinsic motivation has been revealed (Callahan et al., 2003:25192520). The relation between intrinsic motivation, learning styles, and pace and style of technology adoption is illustrated in a later section.

In this article, key human factors contributing towards the e-profile of an employee are identified. These human factors also determine to which extent the above-mentioned motivating factors (self-set or assigned goals, incentives or rewards, and intrinsic motivation) should play a role in the performance appraisal process to make an employee more comfortable with the new job demand, viz. acting as an online learning facilitator. The following sections outline these key human factors.

\section{Key human factors}

The following key human factors are outlined: pace and style of technology adoption, learning styles, and personal profile patterns.

\subsection{Pace and style of technology adoption}

In earlier sections, employees' pace and style of technology adoption have been mentioned. The diffusion model of Rogers (1995) proposes five adopter categories, namely: innovators, early adopters, early majority, late majority, and laggards, as illustrated in Figure 1. Zemsky and Massy (2004:9) use Rogers' categories to illustrate e-learning's pattern of innovation and change. The categories can be summarised as follows: 
- Innovators (2\%): These are learners who enjoy exploring new ideas and are driven by intrinsic motivators.

- Early adopters (13\%): These are learners who adopt once the concept has been proven. They are viewed as opinion leaders and decision-makers who have the vision to adapt an emerging technology to an opportunity, and they are driven by extrinsic motivators. They have the foresight to match an emerging technology strategic opportunity (Oliver, 2001:6).

- Early majority (35\%): These are eventual users of technology who do not like to take the risks of pioneering but see the advantages of tested technologies and are driven by usability and success of the technology; they are the beginning of the mass market.

- Late majority (35\%): These are learners who adopt when half of the population has already done so. They are followers who dislike the disruptions of new technologies and are more conservative.

- Diehards (laggards) (15\%): These are learners who resist adopting innovations and perform the valuable service of regularly pointing out the discrepancies between the day to day reality of the product and the claims made for it (Beshears, s.a.).

Figure 1: Adopter categories defined by Rogers (1995) (Adapted from Beshears, s.a.; and Zemsky \& Massy, 2004)

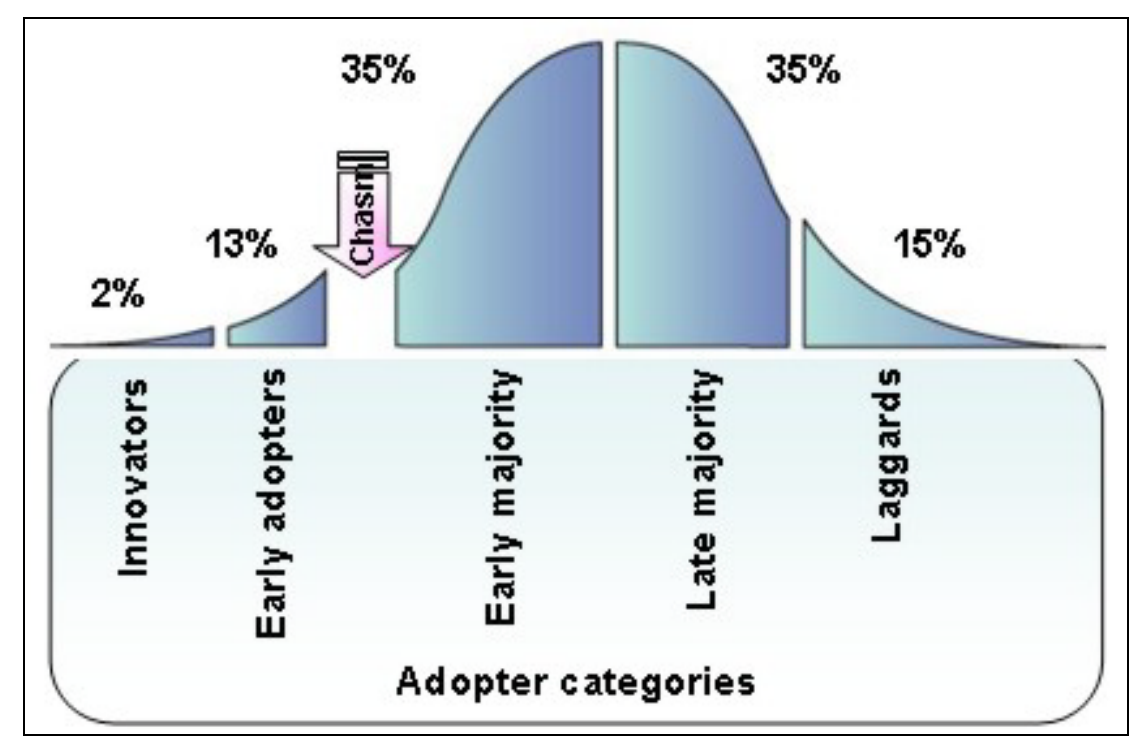


A chasm or time gap develops between the early adopters and the early majority because of their different expectations (Moore, 1991; Wikipedia, 2005; 2006). Failure to identify this gap, which is wedged between pioneering and mainstream employees, or to take up the challenge of closing the gap has resulted in the failure of many potentially successful technology products (Oliver, 2001:6).

It could be argued that employees falling in the early majority and late majority categories of the technology adoption cycle may need to be encouraged to use technology in teaching and learning by the use of incentives or rewards, as there is resistance to some extent, and they need a certain degree of convincing or motivation. Employees in the innovator category will typically be intrinsically motivated and eager to take on challenges. An innovator, therefore, is most likely to embrace the change in job demand and not portray a lack of e-readiness. The early adopter category will also accept the new challenge relatively easily, as they are visionary thinkers, opinion leaders, and change agents. It is important that leaders in HEls focus on closing the gap between these two groups (innovators and early adopters) and the early majority (mass market). Managers in HEls should determine the stage(s) in which technology adoption employees are to determine which motivational strategy should be applied during performance appraisals. Furthermore, once an employee has been plotted on the technology adoption cycle during a performance assessment, the extent to which a lack of e-readiness occurs will be more explicable and will therefore indicate the extent to which further training and development and/or motivation is required.

\subsection{Learning styles}

Employees' learning style preferences will also play a significant role in their adoption of the technology in their teaching, and thus their ereadiness. They should therefore also be included in the performance appraisals of online learning facilitators. For instance, right brain dominated people may prefer an holistic and visual approach, while left brain dominated people may prefer a systematic approach (Vermeulen, 2005:8). Learning styles influence the manner in which individuals attach their own meaning to the subject matter or skill being taught (Roy, 2006:22). Online teaching must be structured in such a manner that it makes provision for all learning styles (Salmon, 2003:110).

Kolb indicates the following four learning styles (Kolb, 1984; 1985a; 1985b; 1999a; 1999b; Kolb \& Kolb, 2005; Swinton, 2006:1-2; Smith, 
2001:5-7; Clark, 2000:1-2; Demirkan, 2008:256; Arp et al., 2006:29; Boyatzis \& Kolb, 1995:3; Dewhurst \& Fitzpatrick, 2007:14):

- Diverging: The diverging learning style encompasses a combination of concrete experience and reflective observation. An individual with this preferred learning style prefers gathering information, is good at brainstorming, strong on imagination, interested in people, sees different perspectives, prefers group work, and is open-minded. The approach is feeling and watching.

- Assimilating: The assimilating learning style is a combination of abstract conceptualisation and reflective observation. An individual with this preferred learning style will follow a concise logical approach. Ideas and concepts are more important to them than people, they prefer lectures, they like to read, are imaginative, enjoy independent study, are less focused on social aspects of learning, enjoy web searches, like self-diagnostic activities, and need time to think. The approach is watching and thinking.

- Converging: The converging learning style is a combination of abstract conceptualisation and active experimentation. An individual with this preferred learning style likes solving practical problems, prefers technical tasks such as experimentation and simulation, and are less interested in interpersonal issues. The approach is doing and thinking.

- Accommodating: The accommodating learning style is a combination of concrete experience and active experimentation. An individual with this preferred learning style prefers a hands-on approach, is attracted to new challenges and experiences, relies on others instead of doing their own analysis, is action oriented, sets targets and work hard in teams to achieve tasks, and is a good adaptor. The approach is doing and feeling.

In addition to Kolb's learning styles, Honey and Mumford (1986) present four learning styles. The first learning style category is activists, who prefer to deal with new challenges and experiences and need to receive a range of activities to keep them interested. The second learning style category is pragmatists, who require a link between the training and the end-result required of them. They will determine the practical value and use of what they are being taught. The third learning style category is theorists, who require good structure and sufficient time to explore the relevance between ideas and scenarios. They are analytical and detail-conscious and need to think things through in a logical, step-by-step manner. The fourth learning style category is reflectors, who spend a significant amount of time 
thinking intensively about the activities and concepts provided to them online. Reflectors is the category that probably benefits the most from web-based teaching and learning. Downing and Chim (quoted by Liu, 2007:41) find that individuals who are reflectors tend to be extroverted in the online environment although they may be introverts in the traditional classroom setting.

It could be argued that online learning facilitators who are activists can be compared to the innovator and early adopter of the technology adoption cycle, who is an employee with a vision of the benefits of technology in teaching and learning. The activist will, however, prefer to be the leader and rather give direction. The pragmatist may be compared to the early majority category of the technology adoption cycle. This group will make the paradigm shift from traditional classroom learning to e-learning once the concept has been proven. The theorist may be compared to the early majority or late majority, needing more time for an employee to become familiar with the use of technology in teaching and learning. They will analyse and review information before they adopt the use of technology in this way, and will eventually make the paradigm shift. Once they adopt the use of technology for e-learning, they tend to flourish in the online environment owing to their systematic and analytical approach (Arp et al., 2006:30). They prefer to analyse the situation first and understand the underlying theories. The reflector, similar to the theorist, may be compared to the early majority and late majority. Prior to adopting the use of technology, they will consider it intensively and listen to others' views, considering them before taking action or incorporating their own views.

Employees who need to take on the role of online learning facilitators will naturally tend towards a particular learning style. These learning styles need to be considered during goal setting and the performance appraisal process when a development plan is drafted. The above-mentioned learning styles should be included in the matrix in which employees can be plotted during the performance assessment.

\subsection{Personal profile patterns}

It is acknowledged that individuals differ in traits, such as skills, aptitudes and preferences for processing information, constructing knowledge from information, and applying it to real-world problem solving. (Magoulas \& Chen, 2005:327.) 
Interpersonal factors are often more significant for an employee's achievement than technical competence. An interpersonal factor that is likely to vary between employees and their managers is work style or preference. When faced with a problem, some individuals adapt solutions in a cautious, systematic manner, whereas others prefer innovative solutions (Xu \& Tuttle, 2004:22).

It is necessary to differentiate between the personal profile preferences of online learning facilitators, in order to determine how they will adapt to the use of technology in teaching and learning and what their likely level of e-readiness will be. The personal profile patterns of the online learning facilitators should be assessed during the performance appraisal process and be included in the matrix. Personal profile patterns is one of the human factors that contribute to the profile of the online learning facilitator and which will play a role in the level of e-readiness of an employee and an employee's perception of the need to incorporate technology in teaching and learning.

A useful and well-known assessment instrument for determining the attributes contributing to an employee's personal profile is the Dominance Influence Steadiness Compliance (DISC) profiling instrument (Thomas International, 2005). A DISC profile reports a style or characteristic of behaviour in a work situation. The DISC profiling instrument thus describes human behavioural pattern styles, in four dimensions. The four dimensions indicate "typical patterns of interaction" of a person in the working environment (Thomas International, s.a.).

- Dominance: This category considers the manner in which problems are addressed. Individuals of this category are concerned with results. They are typically competitive, with high performance standards, and focused on achieving goals, solving problems, and accepting challenges.

- Influence: This category considers the manner in which people are dealt with. Individuals of this category like people and want to be liked in return. They are typically charming, optimistic, and outgoing, and focused on networking, conversation, and working with others.

- Steadiness: This category considers the manner in which an individual paces him-/herself. Individuals of this category are concerned about relations. They are typically sympathetic, friend- 
ly, good listeners, "finisher completers", and team players, who work hard and create a stable environment.

- Compliance: This category considers the manner in which rules and procedures are followed. Individuals of this category are concerned with accuracy and research every aspect of a situation, considering each possibility before making a decision (Witt, s.a.). They typically have high standards, particularly for themselves, can be perfectionists, and prefer systems, processes, procedures, as well as predictable and consistent outcomes.

An online learning facilitator displaying a high dominance factor profile is likely to be motivated and inspired by the challenging and dynamic environment and enjoys experimenting with new technologies at a fast pace. Furthermore, such an online learning facilitator is unlikely to be motivated by incentives and rewards, but is intrinsically motivated and sets challenging goals. Employees with a high dominance factor will typically be innovators on the technology adoption cycle, with the activist learning style.

As with the technology adoption cycle and the learning styles, the personal profile patterns of online learning facilitators need to be included in the performance appraisal process, in order to determine a complete profile and the preferences of the employee. Once the employee has been assessed using these criteria (key human factors), he/she can be plotted on a matrix to determine their level of e-readiness. Subsequently, a development plan can be drafted and training interventions can be planned and executed, with the aim of improving the level of e-readiness of the employee.

\section{Conclusion}

It is evident that it may be necessary for HEls to conduct a needsanalysis in terms of the performance appraisal system, in order to determine whether it needs to be adjusted to incorporate new job demands, such as e-learning, and in particular the assessment of ereadiness effectively. Furthermore, human factors that influence employees' adoption of technology and therefore their level of e-readiness, such as personal profile patterns, pace and style of technology adoption, and learning styles, should be considered in the performance appraisal process and the drafting of a development plan. This will support targeted and relevant training for the new e-learning skill and approach the employee's development and motivation from the most suitable angle. A matrix indicating these human 
factors can be drafted and employees plotted on the matrix, in order to determine their placement in terms of e-learning.

\section{List of references}

ARP, L., WOODARD, B.S. \& MESTRE, L. 2006. Accommodating diverse learning styles in an online environment. Reference \& user services quarterly, 46(2):27-32.

BAINBRIDGE, C. s.a. Intrinsic motivation. http://giftedkids.about.com/od/ glossary/g/intrinsic.htm Date of access: 21 Mar. 2009.

BESHEARS, F.M. s.a. The technology adoption life-cycle. http://istsocrates.berkeley.edu/ fmb/articles/lifecycle/index.html Date of access: 10 Oct. 2005.

BOYATZIS, R.E. \& KOLB, D.A. 1995. From learning styles to learning skills: the executive skills profile. Journal of managerial psychology, 10(5):3-17.

BRIDGES.ORG. 2005a. E-readiness assessment: who is doing what and where? http//:www.bridges.org/publications/40 Date of access: 17 Feb. 2007.

BRIDGES.ORG. 2005b. E-readiness in developing countries: current status and prospects toward the MDG: executive summary. http//:www.bridges. org/publications/18/exec_summary Date of access: 17 Feb. 2007.

CALLAHAN, J.S., BROWNLEE, A.L., BRTEK, M.D. \& TOSI, H.L. 2003. Examining the unique effects of multiple motivational sources on task performance. Journal of applied social psychology, 33(12):2515-2535.

CHOUCRI, N., MAUGIS, V., MADNICK., S. \& SIEGEL, M. 2003. Global ereadiness: for what? Report of the Group for Globalisation of e-Business. Centre for e-Business at Massachusetts Institute of Technology, Sloan School of Management. http//:ebusiness.mit.edu/research/papers/177_ Choucri_GLOBAL_eREADINESS.pdf Date of access: 19 Aug. 2006.

CLARK, D. 2000. Kolb's learning styles. http://www.nwlink.com/ donclark/ hrd/history/kolb.html Date of access: 13 Aug. 2006.

CURTIS, K. 1994. From management goal setting to organizational results: transforming strategies into action. Westport: Quorum.

DEMIRKAN, H. 2008. Focus on the learning styles of freshman design students. Design studies, 29(3):254-266.

DEPARTMENT OF PUBLIC SERVICE AND ADMINISTRATION (DPSA). 2002. Guidelines on integrated human resource planning in the public service. http://www.dpsa.gov.za/documents/ep/2006/HR_PLAN_GUIDELINES.pdf Date of access: 21 Mar. 2009.

DEWHURST, S. \& FITZPATRICK, L. 2007. Why learning is a matter of personal preference. Strategic communication management, 11(3):14.

ECONOMIST INTELLIGENCE UNIT (EIU). 2007. http://www.eiu.co. Date of access: 23 Aug. 2007.

GARAVALIA, L.S. \& GREDLER, M.E. 2008. An exploratory study of academic goal setting, achievement calibration and self-regulated learning. Journal of instructional psychology, 29(4):221-230.

GROBLER, P.A., WÄRNICH, S., CARRELL, M.R., ELBERT, N.F. \& HATFIELD, R.D. 2002. Human resource management in South Africa. 2nd ed. Cornwall: Thompson. 
GUBUKCU, Z. 2008. Preferences on internet-based learning environments in student-centred education. Turkish online journal of distance education, 9(4):154-174.

GULATI, S. 2008. Compulsory participation in online discussions: is this constructivism or normalisation of learning? Innovations in education and teaching international, 45(2):183-192.

HONEY, P. \& MUMFORD, A. 1986. The manual of learning styles. Maidenhead: Honey.

HUNSAKER, P.L. 2001. Training in management skills. New Jersey: PrenticeHall.

IFINEDO, P. 2005. Measuring Africa's e-readiness in the global networked company: a nine-country data analysis. International journal of education and development using information communication technology, 1(1):5371.

KOLB, A.Y. \& KOLB, D.A. 2005. The Kolb learning style inventory: technical specifications. Version 3.1. Boston: Hay.

KOLB, D.A. 1984. Experiential learning: experience as the source of learning and development. New Jersey: Prentice-Hall.

KOLB, D.A. 1985a. Learning style inventory. Revised ed. Boston: Hay.

KOLB, D.A. 1985b. Learning style inventory: technical manual. Boston: Hay.

KOLB, D.A. 1999a. Learning style inventory. Version 3. Boston: Hay.

KOLB, D.A. 1999b. Learning style inventory: technical specifications. Version 3. Boston: Hay.

LI, A. \& BUTLER, A.B. 2004. The effects of participation in goal setting and goal rationales on goal commitment: an exploration of justice mediators. Journal of business and psychology, 19(1):37-51.

LIU, Y. 2007. A comparative study of learning styles between online and traditional students. Journal of educational computing research, 37(1):4163.

LOCKE, E.A. \& LATHAM, G.P. 1990. Work motivation and satisfaction: light at the end of the tunnel. American Psychological Society, 1(4):240-246.

MACHADO, C. 2007. Developing an e-readiness model for HEls: results of a focus group study. British journal of educational technology, 38(1):72-82.

MAGOULAS, G. \& CHEN, S. 2005. Advances in web-based education: personalized learning environments. Hershey: Information Science Publishing.

MASTERNEWMEDIA. 2002. Online assessment and e-readiness evaluation tools for students and trainers. http://www.masternewmedia.org/ 2002/03/31/online_assessment_and_ereadiness_evaluation_tools_for_stu dents_and_trainers.html Date of access: 12 May 2007.

MAUGIS, V., CHOUCRI, N., MADNICK, S.E., SIEGEL, M.D., GILLETT, S.E., HAGHSETA, F., ZHU, H. \& BEST, M.L. 2005. Global e-readiness: for what? Readiness for e-banking. Information technology for development, 11(4):313-342.

MCCONNELL INTERNATIONAL. 2001. Ready? Net. Go! Partnerships leading the global economy. http://www.mcconnellinternational.com Date of access: 12 May 2007.

MINER, J.B. \& CRANE, D.P. 1995. Human resource management: the strategic perspective. New York: HarperCollins.

MOORE, G.A. 1991. Crossing the chasm. New York: HarperCollins. 
MUTULA, S.M. 2006. An assessment of e-readiness of small and medium sized enterprises in the ICT sector in Botswana, with special reference to information access. Johannesburg: University of Johannesburg. (Unpublished doctoral thesis.)

NYKODYM, N. 1996. Public sector performance appraisal and effectiveness: a case study. http://www.allbusiness.com/human-resources/employeebenefits/567661-1.html Date of access: 21 Mar. 2009.

OLIVER, C. 2001. Taking policy governance to the mainstream: some insights from the world of new technologies. Board leadership, (53):6-8, Jan.-Feb.

RADEMAN, D.J. \& DE VOS, H.D. 2001. Performance appraisals in the public sector: are they accurate and fair? Journal of industrial psychology, 27(1):54-60.

REES, W.D. \& PORTER, C. 2003. Appraisal pitfalls and the training implications. Part 1. Industrial and commercial training, 35(7):280-284.

REPUBLIC OF SOUTH AFRICA. 1996. Constitution of the Republic of South Africa, Act 108 of 1996, 11 Oct. Pretoria: Government Printer.

ROBBINS, S.P. 2003. Organizational behaviour. 10th ed. New Jersey: PrenticeHall.

ROGERS, E.M. 1995. Diffusion of innovations. 4th ed. New York: Free Press.

ROY, K. 2006. The impact of learning styles on interactivity in asynchronous elearning. Performance improvement, 45(10):22.

SALMON, G. 2003. E-moderating: the key to teaching and learning online. 2nd ed. London: Taylor \& Francis.

SCHOOLNET AFRICA. 2003. e-Readiness as a tool for ICT development. http//:www.schoolnetafrica.net/fileadmin/resources/E-readiness_as_a_ tool.pdf Date of access: 17 Apr. 2007.

SCHULER, R.S. 1981. Applied readings in personnel and human resource management. St. Paul: West.

SHAMIR, B. 1996. Meaning, self and motivation in organizations. (In Steers, R.M., Porter, L.W. \& Bigley, G.A., eds. Motivation and leadership at work. 6th ed. New York: McGraw-Hill. p. 149-165.)

SMITH, M.K. 2001. David A. Kolb on experiential learning. http://www.infed. org/b-explrn.htm Date of access: 11 Oct. 2008.

SWINTON, L. 2006. Kolb's learning style inventory and Kolb's learning cycle explained: no fluff, no filler, just facts. http://www.mftrou.com/kolb-learningstyle-inventory.html Date of access: 12 Oct. 2006.

THOMAS INTERNATIONAL. 2005. DISC profiling instruments: resources provided by Thomas International registered analyst.

THOMSON, R. \& MABEY, C. 2001. Developing human resources. Oxford: Butterworth-Heinemann.

VERMEULEN, L. 2005. The perceived usefulness of WebCT training for public management students at the Tswane University of Technology. Paper delivered at the Conference of the International Association of Schools and Institutes in Administration (IASIA), 11-15 July 2005, Como, Italy.

VERMEULEN, L. 2006. Focus group discussion on e-learning. Pretoria. 13 Nov. WIKIPEDIA. 2005. Early adopter. http://en.wikipedia.org/wiki/Early_adopter Date of access: 21 Mar. 2009.

WIKIPEDIA. 2006. Crossing the chasm. http://en.wikipedia.org/wiki/Crossing_ the_Chasm Date of access: 21 Mar. 2009.

WILSON, J.P. 2005. Human resource development: learning and training for individuals and organisations. London: Page. 
WITT, C. s.a. What is DISC? http://www.wittcom.com/what_is_disc.htm Date of access: 21 Mar. 2009.

XU, Y. \& TUTTLE, B.M. 2004. Understanding work styles. Business and economic review, 22-24. Oct.-Dec.

ZEMSKY, R. \& MASSY, W.F. 2004. Thwarted innovation: what happened to elearning and why. http://www.irhe.upenn.edu/Docs/Jun2004/Thwarted Innovation.pdf Date of access: 21 Mar. 2009.

\section{Key concepts:}

e-readiness

human resource: performance appraisal

key human factors

online learning facilitator

staff motivation

technology adoption

\section{Kernbegrippe:}

e-gereedheid

kern menslike faktore

menslike hulpbron: prestasie-evaluering

personeelmotivering

tegnologie-aanpassing

web-gerugsteunde leerfasiliteerders 
